\title{
Lactobacilli carry cryptic genes encoding peptidase-related proteins: characterization of a prolidase gene (pepQ) and a related cryptic gene (orfZ) from Lactobacillus delbrueckii subsp. bulgaricus
}

\author{
Terhi Rantanen ${ }^{1,2}$ and Airi Palva ${ }^{1}$ \\ Author for correspondence: Airi Palva. Tel: +358 34188 277. Fax: +358 34188444. \\ e-mail: airi.palva@mtt.fi
}

\footnotetext{
1 Agricultural Research Centre of Finland, Food Research Institute, Jokioinen 31600, Finland

2 University of Turku, Department of Biochemistry and Food Chemistry, Turku 20014, Finland
}

\begin{abstract}
Two genes, pepQ and orfZ, encoding a prolidase and a prolidase-like protein, respectively, were cloned and characterized from Lactobacillus delbrueckii subsp. bulgaricus. The identity of the pepQ and orfZ genes with the Lactobacillus delbrueckii subsp. lactis prolidase gene (pepQ) was shown to be $98 \%$ and $60 \%$, respectively. Both pepQ and orfZ were preceded by a putative promoter region. Northern analysis of pepQ mRNA revealed a $1.1 \mathrm{~kb}$ transcript indicating that pepQ forms a monocistronic transcriptional unit. Under the growth conditions used, no evidence was obtained that orf $Z$ was expressed, either by mRNA size determination in Northern analysis or by primer extension analysis. With reverse transcription-PCR, however, the presence of monocistronic orfZ transcripts was established. The orfZ gene could also be overexpressed in E. coli using the vector pKK223-3. The size of the protein synthesized, $41 \mathrm{kDa}$, confirmed the molecular mass of OrfZ calculated according to DNA sequence analysis. In contrast to PepQ, which showed a substrate specificity characteristic of prolidase enzymes, no enzymic activity for the orfz-encoded protein was found with the peptide substrates tested. These results indicate that orf $Z$ is a cryptic gene, which is expressed at a very low level under the growth conditions used. It is noteworthy that homologues of the $L b$. delbrueckii subsp. bulgaricus orfZ and pepQ genes appeared to be present in both Lb. delbrueckii subsp. lactis and Lactobacillus helveticus.
\end{abstract}

Keywords: Lactobacillus delbrueckii subsp. bulgaricus, prolidase, peptidase, pepQ

\section{INTRODUCTION}

Lactic acid bacteria (LAB) have a limited capacity to synthesize amino acids and are, therefore, dependent on exogenous nitrogen sources for optimal growth. When growing in milk, LAB utilize complex proteolytic systems for the degradation of milk proteins. The biochemical and genetic characterization of these systems from lactococci and lactobacilli have been

\footnotetext{
Abbreviation: RT, reverse transcription.
}

The EMBL accession numbers for the nucleotide sequences of the Lactobacillus delbrueckii subsp. bulgaricus orfZ and pepQ genes reported in this paper are $Z 93945$ and Z93944, respectively. investigated in a number of laboratories (Kok, 1990; Pritchard \& Coolbear, 1993; Tan et al., 1993; Visser, 1993 ; Kok \& De Vos, 1994), and shown to comprise a cell-envelope-associated proteinase, membrane-bound transport systems and several cytoplasmic peptidases. The manufacture of fermented food by $\mathrm{LAB}$ would benefit from a more detailed understanding of proteolysis. In cheese manufacturing, the proteolytic activity of $\mathrm{LAB}$ contributes to the ripening process and is known to be essential for the formation of flavour and texture. Peptidases are considered to be particularly important for flavour development. The milk proteins contain a high amount of proline residues which, in free form, give a sweet flavour to cheese (Biede \& Hammond, 1979; Fox, 1989). Thus, proline-specific peptidases play 
a very important role in cheese ripening by degrading proline-containing peptides, which often are bitter, and by making peptides accessible to the action of other peptidases by removal of proline residues (Baankreis \& Exterkate, 1991).

Several proline-specific peptidases with distinct substrate specificities have been found in LAB. To date prolinase, prolidase, proline iminopeptidase, aminopeptidase $\mathrm{P}$ and $\mathrm{X}$-prolyl dipeptidyl aminopeptidase activities have been detected and genes responsible for these activities characterized (Fernández-Esplá et al., 1997; Kunji et al., 1996). In this work, we describe two new genes, $p e p Q$ and orf $Z$, from Lactobacillus delbrueckii subsp. bulgaricus B14. The pepQ gene encodes prolidase activity, whereas orf $Z$, even though showing high homology to $p e p Q$-like genes, was found to have a cryptic function under the experimental conditions used.

\section{METHODS}

Bacterial strains, plasmids and culture conditions. $L b$. delbrueckii subsp. bulgaricus B14 (Federal Dairy Research Centre, Kiel, Germany) was grown in MRS broth (Difco) at $42{ }^{\circ} \mathrm{C}$. For $\mathrm{pH}$-controlled cultivation, a Biostat B (B. Braun Biotech International) bioreactor was used. The $\mathrm{pH}$ was maintained at 6.0 by addition of $1 \mathrm{M}$ aqueous ammonia solution with slow agitation. Lactobacillus helveticus $53 / 7$ (Valio) was grown in milk or MRS at $42^{\circ} \mathrm{C}$. Lactobacillus delbrueckii subsp. lactis DSM 20072 (DSMZ) was grown in MRS at $37^{\circ} \mathrm{C}$. Escherichia coli strains DH5 $\alpha \mathrm{F}^{\prime}$ (Woodcock et al., 1989), JM105 (Pharmacia) and NM514 (Amersham) were grown in Luria broth (L broth) and E. coli strain CM89 (Miller \& Schwartz, 1978) in L broth supplemented with $0.3 \mathrm{mM}$ thymine and $0.05 \mathrm{mM}$ thiamin. Erythromycin $\left(0.3 \mathrm{mg} \mathrm{ml}^{-1}\right)$ and ampicillin $\left(0.05 \mathrm{mg} \mathrm{ml}^{-1}\right)$ were added when using the vectors pJDC9 (Chen \& Morrison, 1987) and pKK223-3 (Pharmacia), respectively, in E. coli.

DNA isolation, synthesis and transformation methods. $L b$. delbrueckii and $\mathrm{Lb}$. helveticus chromosomal DNA was isolated as described by Vidgren et al. (1992) without a guanidine hydrochloride treatment. Phage DNA was isolated according to the instructions of the cDNA rapid cloning module ( $\lambda \mathrm{gt} 10$; Amersham). Plasmid DNA was isolated from E. coli by alkaline lysis with the Wizard (Promega) and FlexiPrep (Pharmacia) DNA purification systems. Oligonucleotides were synthesized with an Applied Biosystems DNA/RNA synthesizer model 392 and purified by ethanol precipitation or with NAP-10 columns (Pharmacia Biotech). For DNA synthesis, performed by PCR, the Dynazyme DNA polymerase (Finnzymes) was used under the reaction conditions recommended by the manufacturer. Other DNA techniques were as described by Sambrook et al. (1989). E. coli strains were transformed by electroporation using a Bio-Rad Gene Pulser.

Cloning of the $\mathbf{L b}$. delbrueckii subsp. bulgaricus orf $Z$ and pepQ genes and Southern analyses. An Lb. delbrueckii subsp. bulgaricus genomic library was constructed in $\lambda \mathrm{gt} 10$ using $\lambda$ DNA in vitro packaging and cDNA rapid cloning modules ( $\lambda \mathrm{gt} 10$; Amersham). Instead of the Amersham cDNA rapid ligation module, a RiboClone EcoRI Linker Ligation System (Promega) was employed. During a screening of the $L b$. delbrueckii subsp. bulgaricus library for the operon of the oligopeptide transport system, a hybridization-positive clone was found showing DNA homology to the $L b$. delbrueckii subsp. lactis DSM 7290 prolidase gene (pepQ) (Stucky et al., 1995). For further elucidation and cloning of the missing region of this $p e p Q$-like gene, called here orf $Z$, a Southern blot analysis of the $L b$. delbrueckii subsp. bulgaricus chromosomal DNA was performed using a orf $Z$-specific $0.5 \mathrm{~kb}$ fragment amplified by PCR as a hybridization probe. The primer pair used for PCR was 5' TTTGACTTGGGGATCATG $3^{\prime}$ and $5^{\prime}$ TTGGGTATGACCAAATAGC $3^{\prime}$, and the $\lambda$ clone, carrying part of the orf $Z$ gene, served as the template. The hybridization-positive fragment pool was cloned in $E$. coli using pJDC9 followed by screening of the orfZ-specific transformants.

For cloning of $p e p Q$, the upstream and coding regions of the pepQ gene were cloned in pJDC9 as a PCR product synthesized with the primer $5^{\prime}$ TTGTGCAATCGCTTACAG $3^{\prime}$ (p290), designed according to the upstream region of $L b$. delbrueckii subsp. lactis pepQ (Stucky et al., 1995) and with the $L b$. delbrueckii subsp. bulgaricus pepQ-specific primer $5^{\prime}$ TTTGGCTGCACCGTGTTC 3' (p288, which was derived from a sequenced PCR fragment generated with $L b$. delbrueckii subsp. lactis-specific primers from the chromosomal DNA of Lb. delbrueckii subsp. bulgaricus). The missing $3^{\prime}$ end and the downstream region of $p e p Q$ was identified by Southern hybridization using the above $p e p Q$ PCR fragment as the hybridization probe. The resulting hybridization positive $1.3 \mathrm{~kb}$ HindIII-SalI fragment pool was ligated with pJDC9 and the ligation mixture was directly used as the template in PCR with the $p e p Q$-specific primer $5^{\prime}$ ACACGGTGCAGCCAAATG 3' (p287) and a biotinylated vectorspecific primer. After PCR sequencing of the $3^{\prime}$ end obtained, the entire $p e p Q$ was synthesized by PCR with the specific primers designed for the upstream and downstream regions of the gene (p290 and 5' ACGATTCAGCTAACGGCG 3', p318) and cloned in PJDC9.

The probes for Southern blots were labelled with digoxigenindUTP (DIG, Boehringer Mannheim). Hybridizations were performed under high stringency conditions and when necessary with different stringencies $\left(68^{\circ} \mathrm{C}, 60^{\circ} \mathrm{C}\right.$ and $50^{\circ} \mathrm{C}$ overnight, followed by washes with $0.5 \times \mathrm{SSC}, 0.1 \% \mathrm{SDS}$ at $68^{\circ} \mathrm{C}, 55^{\circ} \mathrm{C}$ and $45^{\circ} \mathrm{C}$ ). A DIG Luminescent Detection Kit (Boehringer Mannheim) was used for hybrid detection.

DNA sequencing and sequence analysis. Sequencing was performed on an A.L.F. DNA Sequencer (Pharmacia). The dideoxy sequencing reactions (Sanger et al., 1977) were performed according to the AutoRead Sequencing Kit manual (Pharmacia). Both DNA strands were sequenced using pUC19specific primers and sequence-specific oligonucleotides for primer walking. DNA sequences were assembled and analysed with the PC/GENE programs (release 6.85; IntelliGenetics). For homology searches, the databases of EMBL and SWISS-PROT were used both as a CD-ROM version (release 15.0, June 1995) and directly by e-mail with the EMBL BLITZ server.

RNA methods. Total RNA from different phases of growth was isolated from $\mathrm{Lb}$. delbrueckii subsp. bulgaricus cells essentially as described by Palva et al. (1988) and Vesanto et al. (1994). RNA gel electrophoresis and Northern blots were performed as described previously (Hames \& Higgins,1985). Hybridization probes were labelled with $\left[\alpha^{-32} \mathrm{P}\right] \mathrm{dCTP}$ [ $>3000 \mathrm{Ci} \mathrm{mmol}^{-1}\left(111 \mathrm{TBq} \mathrm{mmol}^{-1}\right)$; Amersham] with a random-primed DNA labelling kit (Amersham) or with nonradioactive DIG. The primer extension of orf $Z$ was performed with total RNA using an A.L.F. DNA Sequencer essentially as described by Myöhänen \& Wahlfors (1993) and 
Vesanto et al. (1995) with $10 \mathrm{pmol}$ of the oligonucleotide $5^{\prime}$ TTCATTGATCGCCGGAGC 3' labelled with fluorescein.

Reverse transcription (RT)-PCR of orfZ mRNA was performed as follows. Two cDNA preparations were synthesized by RT (AMV reverse transcriptase, Promega) using $1.5 \mu \mathrm{g}$ total Lb. delbrueckii subsp. bulgaricus RNA. The oligonucleotides used in the first-strand synthesis were $5^{\prime}$ TTCCCGGCTCCAGATTCAC 3' (p459) and 5' AGCAGCAAAGCCATCTTACTG 3' (p174), being complementary to the orfZ-specific mRNA derived from ORF2 and its downstream region (ORF3), respectively. These cDNA samples were phenol-extracted, precipitated and dissolved in $20 \mu \mathrm{l} \mathrm{H}_{2} \mathrm{O}$. Amplifications by PCR were performed with $3 \mu \mathrm{l}$ cDNA samples. The oligonucleotides 5' ATGTGGCAGAGCCAGTGGAC 3' (p458) and 5' CAAGTGGGTGATTATCAGC 3' ( $\mathrm{p} 234$ ), binding to orfZ (ORF2) and the upstream region of ORF2, respectively, were used with the orfZ-specific primer 459. A PCR reaction was also performed with the orf $Z$ primer 458 and the downstream ORF3 primer 174. As a control for the absence of contaminating DNA, $5 \mu \mathrm{g}$ total RNA was directly amplified by PCR using the primer pair $458 / 459$.

Peptidase activity assays. Peptidase activity was determined in liquid cultures of $E$. coli by a coupled enzyme reaction containing peroxidase, L-amino-acid oxidase and $O$ dianisidine (Wohlrab \& Bockelmann, 1992). Cells were disrupted with an Ultrasonic 2000 sonicator (Braun). The reaction volume was $1 \mathrm{ml}$ and samples were incubated at $37^{\circ} \mathrm{C}$ for $30-60 \mathrm{~min}$. For characterization studies, enzyme activity was determined by two alternative methods: the iminopeptidase (proline-liberating) activity was determined using the modified method of Troll \& Lindsley (1955) as described by Baankreis \& Exterkate (1991). The hydrolysis of peptides not containing proline as the amino-terminal residue was assayed by measuring the release of $\alpha$-amino acids by the modified cadmium-ninhydrin method described by Doi et al. (1981). All activity assays were performed with at least two parallel samples.

Construction of an overexpression system for the $\boldsymbol{L b}$. delbrueckii subsp. bulgaricus orfZ. For overexpression in $E$. coli, the orf $Z$ gene was synthesized by PCR using primers 243 and $5^{\prime}$ AACAAGATGTCTCCAAGCCTG 3' (p179). The $1.7 \mathrm{~kb}$ PCR product was digested and ligated as a $1.5 \mathrm{~kb}$ EcoRI-HindIII fragment into the pKK223-3 vector and transferred into the E. coli JM105 host by electroporation. Expression of orf $Z$ was characterized by growing the cells to a density of 50 Klett units (filter 66) followed by $1 \mathrm{mM}$ IPTG induction and estimation of product accumulation over $5 \mathrm{~h}$ by SDS-PAGE.

\section{RESULTS AND DISCUSSION}

\section{Cloning and sequencing of the orf $Z$ region from $L b$. delbrueckii subsp. bulgaricus}

The $3^{\prime}$ end of a gene, here referred to as orf $Z$, showing significant homology to the Lb. delbrueckii subsp. lactis prolidase gene (pepQ) (Stucky et al., 1995) was found during cloning of genes of the oligopeptide transport system from an $L b$. delbrueckii subsp. bulgaricus $\lambda$ library. The sequenced part of orf $Z$ encoded 138 amino acids and was found to show an identity of $65 \%$ at the amino acid level with the $L b$. delbrueckii subsp. lactis $p e p Q$. However, the expected identity of $L b$. delbrueckii subsp. bulgaricus and $L b$. delbrueckii subsp. lactis prolidases should be higher considering the close relatedness of these two subspecies. This suggested that the orf $Z$ gene product could be a novel prolidase. To localize and clone the entire orf $Z$ gene, an orf $Z$-specific probe was synthesized by PCR for Southern analysis of the $L b$. delbrueckii subsp. bulgaricus chromosomal DNA. A hybridization-positive $3 \cdot 2 \mathrm{~kb}$ BamHI-HindIII fragment was found, cloned into pJDC9 and designated pKTH2141, followed by DNA sequencing of the insert. The DNA sequence of the $3.2 \mathrm{~kb}$ insert revealed three open reading frames (ORF1, ORF2 and ORF3) of 735 , 1119 and 885 bp, respectively. ORF2, hybridizing with the $\operatorname{orf} Z$ probe, had a capacity to encode a protein of 373 amino acids with a calculated molecular mass of $41.4 \mathrm{kDa}$. A putative promoter region (TTGGAT-16 ntTATGAT) and a ribosome-binding site (gGGAGtg) were found 96 and 7 nucleotides upstream of the start codon (ATG) (Fig. 1a), respectively. A inverted repeat structure with a $\Delta G$ of $-23.5 \mathrm{~kJ} \mathrm{~mol}^{-1}$ (Tinoco et al., 1973) was detected 23 nucleotides downstream of the stop codon, representing a putative weak transcription terminator.

The predicted amino acid sequence of ORF2/orfZ showed $62 \%$ similarity with the PepQ of $L b$. delbrueckii subsp. lactis DSM 7290 (Fig. 1b). At the nucleic acid level the corresponding identity was $60 \%$. Since the identity of two proline iminopeptidases, characterized earlier from $L b$. delbrueckii subsp. bulgaricus CNRZ 397 (Gilbert et al., 1994) and Lb. delbrueckii subsp. lactis DSM 7290 (Klein et al., 1994), is $98 \%$, the result obtained here suggests that orf $Z$ is not indeed the counterpart of the Lb. delbrueckii subsp. lactis pepQ. Further analysis of the putative orfZ-encoded protein with the PC/GENE set of programs revealed that the protein would not possess any transmembrane or membrane-associated helices or hydrophobic segments likely to be part of a signal peptide, thus suggesting that OrfZ would be a cytoplasmic protein.

Both ORF1 and ORF3 were found to be preceded by a putative promoter sequence upstream of the respective start codons. However, their deduced amino acid sequences did not show any significant similarity with other proteins found in the databases.

\section{Sequencing of the pepQ gene from $L b$. delbrueckii subsp. bulgaricus}

For comparison of the Lb. delbrueckii subsp. bulgaricus prolidases, the expected counterpart of the $L b$. delbrueckii subsp. lactis pepQ gene was cloned (see Methods) from Lb. delbrueckii subsp. bulgaricus by taking advantage of the published sequence of the $L b$. delbrueckii subsp. lactis pepQ gene (Stucky et al., 1995).

The plasmid clones obtained (pKTH2145, pKTH2146 and $\mathrm{pKTH} 2147$ ) were sequenced; $p e p Q$ was shown to be $1104 \mathrm{bp}$ in length and to encode a protein of 368 amino acids with a calculated molecular mass of $41 \mathrm{kDa}$. A putative promoter had two identical -35 regions (TTTTCA) located 13 and 23 nucleotides upstream of 
(a) $-35$ $-10$

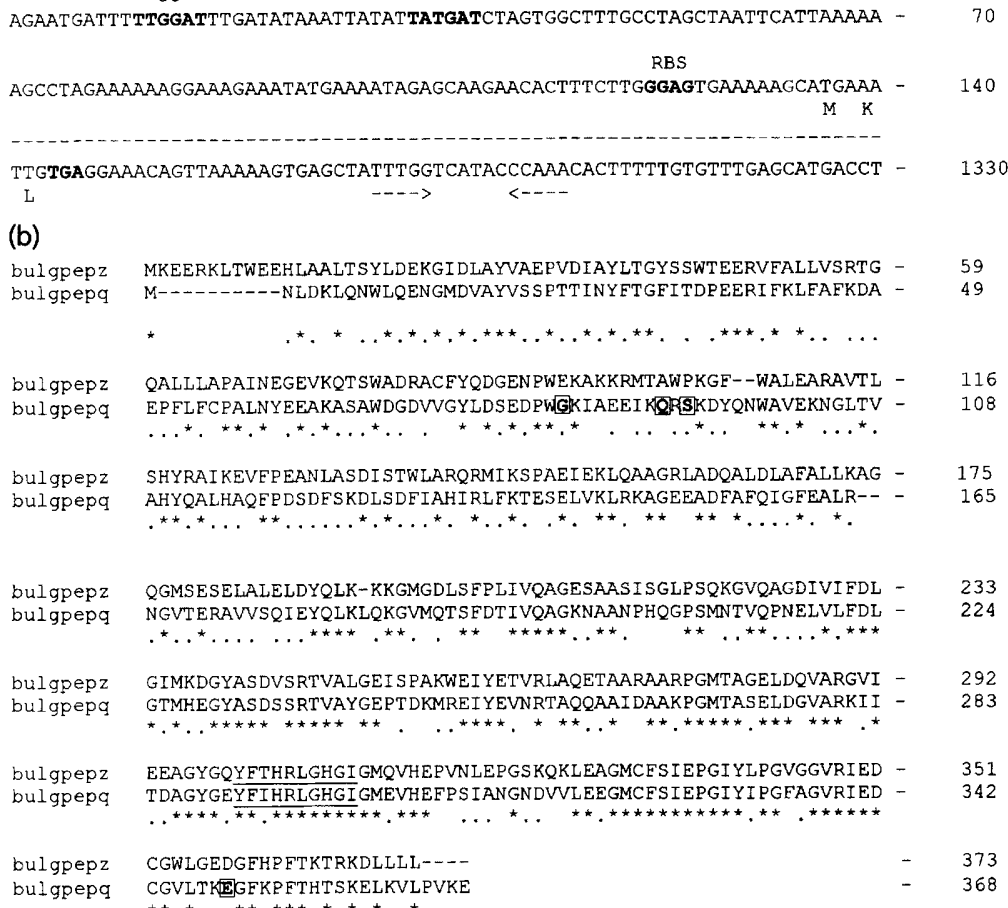

\begin{abstract}
Fig. 1. Partial nucleotide sequence of the Lb. delbrueckii subsp. bulgaricus orfZ gene and alignment of the deduced amino acid sequences of the $L b$. delbrueckii subsp. bulgaricus OrfZ and PepQ. (a) The predicted -35 and -10 regions of the putative promoter and stop codon of the orfZ gene are shown in bold type. RBS indicates the putative ribosome-binding site. The deduced transcription terminator is marked with dashed arrows. (b) Identical and similar amino acids in the OrfZ (bulgpepz) and PepQ (bulgpepq) proteins are indicated by asterisks and dots, respectively. The four amino acids which differed between $L b$. delbrueckii subsp. bulgaricus and $L b$. delbrueckii subsp. lactis PepQ are shown in bold and boxed. The conserved amino acid residues of the putative catalytic site with the zinc-binding domains of metalloproteases are underlined (Jongeneel et al., 1989).
\end{abstract}

the putative -10 region (TATACT).The ribosomebinding site (AGGAGaA) was found seven nucleotides upstream of the start codon ATG. An inverted repeat structure with $\Delta G$ of $-71,1 \mathrm{~kJ} \mathrm{~mol}^{-1}$ was detected 13 nucleotides downstream of the stop codon, representing the putative transcription terminator. At the nucleic acid level, the $L b$. delbrueckii subsp. bulgaricus and $L b$. delbrueckii subsp. lactis pep $Q$ genes showed an identity of $98 \%$ and only four amino acids differed in the predicted amino acid sequences of the two PepQ proteins (Fig. 1b). Two of the amino acid changes were between similar amino acids: Glu-34 and Ser-93 in the Lb. delbrueckii subsp. bulgaricus PepQ were replaced by Asp and Thr in the $L b$. delbrueckii subsp. lactis PepQ, respectively. In addition, Gly-83 and Gln-91 in the $L b$. delbrueckii subsp. bulgaricus PepQ were replaced by Ser and Lys, respectively, in the $L b$. delbrueckii subsp. lactis PepQ. The upstream regions of these two pep $Q$ genes were also very similar, containing only two different nucleotides over the region extending 91 bp upstream of ATG. In contrast, the downstream regions were found to be quite different, with the $93 \mathrm{bp}$ region downstream of the stop codon showing only $42 \%$ identity.

\section{mRNA analyses}

Several attempts were made to determine the size of $L b$. delbrueckii subsp. bulgaricus orfZ $\mathrm{mRNA}$ by Northern blot analysis of samples taken at different phases of growth. The orf $Z$-specific probe used was labelled either with digoxigenin or with the more sensitive radioactive $\left[\alpha{ }^{32} \mathrm{P}\right] \mathrm{dCTP}$. No orfZ-derived transcripts could be detected, even though RNA samples of up to $100 \mu \mathrm{g}$ were tested (data not shown). However, the presence of orfZ-specific mRNA could be identified by RT-PCR (data not shown). The only PCR product detected was with internal orfZ-specific primers ( $\mathrm{p} 458$ and $\mathrm{p} 459$, see Methods). The primer pair used was orfZ-specific and did not give a PCR product with the isolated $p e p Q$ plasmid pKTH2147. No PCR products were amplified by RT-PCR using primers based on sequences located external to orfZ (data not shown). The absence of contaminating DNA in the RNA preparations was also confirmed. These results indicate that orf $Z$ is transcribed as a monocistronic unit. However, the $5^{\prime}$ end mapping by primer extension and a subsequent analysis by an A.L.F. DNA Sequencer failed to detect orf $Z$ transcripts (data not shown), further confirming that the expression level of orf $Z$ was extremely low under the growth conditions employed. Instead, the expression of $p e p Q$, and the size of the pepQ mRNA was determined as a function of growth from $L b$. delbrueckii subsp. bulgaricus cells by Northern blotting, which showed a $1.1 \mathrm{~kb}$ transcript and confirmed that the $p e p Q$ gene also forms a monocistronic transcriptional unit (Fig. 2). Furthermore, the highest level of $p e p Q$ transcripts per unit dry weight of cells was obtained at the midexponential phase followed by a slow decrease in the relative amount of $p e p Q$ mRNAs throughout the remainder of the growth phase (Fig. 2).

\section{Characterization of the OrfZ and PepQ proteins}

To study the enzymic activity of OrfZ, the orfZ gene in pJDC9 was transferred into the peptidase-negative $E$. coli strain CM89, resulting in plasmid pKTH2142. 


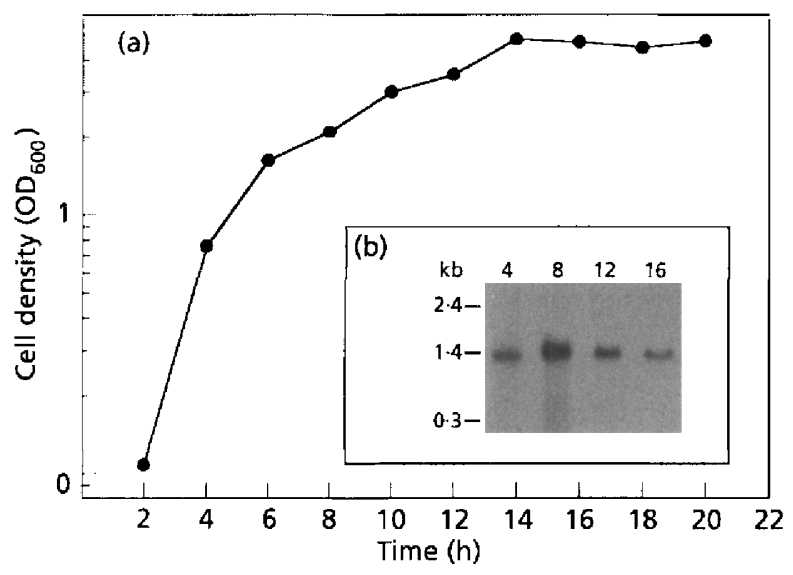

Fig. 2. Expression of the $L b$. delbrueckii subsp. bulgaricus B14 pepQ. (a) Cell density shown as a function of growth. (b) Northern blot analysis of pepQ mRNA from samples taken 4,8 , 12 and $16 \mathrm{~h}$ after inoculation. For quantification of pepQ transcripts, volumes of total RNA were adjusted to equalize the differences in cell dry weights, except for the RNA sample taken at $4 \mathrm{~h}$ where an eightfold lower amount of total RNA was available for analysis. The level of pepQ transcripts was determined by densitometric quantification. Numbers on the left hand side refer to RNA molecular mass markers (BRL).

However, no enzymic activity against the 19 substrates listed in Table 1 could be demonstrated. To test the functionality of OrfZ, the orf $Z$ gene in pKK223-3 was overexpressed in E. coli JM105(pKTH2143) and the expected $41 \mathrm{kDa}$ product was obtained (Fig. 3). The overproduced OrfZ in JM105 cell extracts did not, however, hydrolyse the peptide substrates tested, leaving the specificity of Orf $Z$ unelucidated (Table 1). Thus, Orf $Z$ could either require a very specific substrate or it could represent a degenerated form of a prolidase that has lost its original activity. The expression level of orf $Z$ is likely to be very low since, in addition to the observed transcript levels, the codon usage of orf $Z$, unlike that of $p e p Q$, has a bias typical of poorly expressed genes (Pouwels \& Leunissen, 1994). It is also noteworthy that the amino acid sequence homology between OrfZ and

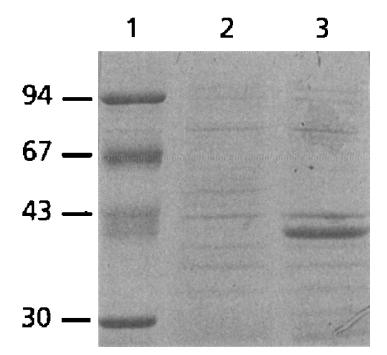

Fig. 3. SDS-PAGE analysis of the orfZ gene product in $E$. coli. Lane 1, molecular mass markers; lanes 2 and 3 , crude extracts isolated $1 \mathrm{~h}$ after IPTG induction from $E$. coli JM105 with the pKK223-3 vector and from $E$. co/ $i \mathrm{JM} 105$ with pKK223-3 carrying the orfZ gene (pKTH2143), respectively.

PepQ is substantially lower in the amino-terminal half than that in the carboxy-terminal half. Interestingly, Klein et al. (1997) have also recently reported a gene (orfW) that is highly homologous to the aminopeptidase genes pepC and $p e p G$, but does not encode a measurable function.

The enzymic activity of PepQ was studied after cloning of the pepQ gene in pJDC9 in E. coli CM89 to form pKTH2140. PepQ hydrolysed all dipeptides tested containing proline at the carboxy-terminal end, with the exception of Pro-Pro. The other peptides tested were not degraded (Table 1). This is in accordance with the classification of $p e p Q$ as an X-Pro dipeptidase gene. Degradation of peptide substrates by the $L b$. delbrueckii subsp. lactis PepQ (Stucky et al., 1995; indicated by an asterisk in Table 1) suggests that the substrate specificity of $L b$. delbrueckii subsp. bulgaricus PepQ is much more stringent than that of $L b$. delbrueckii subsp. lactis. However, this could be due to the differences in the assay systems used for determination of peptidase activities rather than true differences in the specificities of these two enzymes. As with other prolidases characterized, EDTA was strongly inhibitory to $L b$. delbrueckii subsp. bulgaricus PepQ, whereas PMSF had no effect on PepQ activity. The effect of thiol inhibitors on PepQ enzymes has been shown to be in most cases moderate (Booth et al., 1990; Fernández-Esplá et al., 1997;

Table 1. Peptide substrate specificities of $L b$. delbrueckii subsp. bulgaricus PepQ

+ and - indicate hydrolysis and lack of hydrolysis of the substrate tested, respectively.

\begin{tabular}{|lccccccccc|}
\hline Substrate & Hydrolysis & Substrate & Hydrolysis & Substrate & Hydrolysis & Substrate & Hydrolysis & Substrate & Hydrolysis \\
\hline Ala-Pro & $+*$ & Leu-Leu & $-*$ & Ile-Val & - & Pro-Pro & $-*$ & Ile-Pro-Leu & $-\dagger$ \\
Leu-Pro & $+*$ & Met-Leu & $-*$ & Leu-Val & $-*$ & Pro-Ala & $-*$ & Val-Pro-Leu & $-*$ \\
Met-Pro & $+*$ & Phe-Leu & $-*$ & Phe-Val & $-{ }^{*}$ & Pro-Val & $-\dagger$ & Pro-Gly-Gly & $-\dagger$ \\
Val-Pro & $+*$ & Val-Leu & $-{ }^{*}$ & Ala-Met & - & & Leu-Leu-Leu \\
\hline
\end{tabular}

"Substrate hydrolysed by the Lb. delbrueckii subsp. lactis PepQ (all X-Pro substrates are hydrolysed by this enzyme) (Stucky et. al., 1995).

† Data for the Lb. delbrueckii subsp. lactis PepQ not available. 
Kaminogawa et al., 1984), whereas an almost complete inhibition of $L b$. delbrueckii subsp. bulgaricus PepQ was obtained with $1 \mathrm{mM} p$-hydroxymercuribenzoate in this study.

\section{Distribution of orfZ and pepQ}

To test the distribution of orf $Z$ and $p e p Q$ in $L b$. delbrueckii subsp. bulgaricus and Lb. belveticus, Southern blots with different hybridization stringencies were performed using DIG-labelled orf $Z$ and $p e p Q$ probes. The Southern blot analyses showed that, in addition to $L b$. delbrueckii subsp. bulgaricus, $L b$. helveticus also possesses both a $p e p Q$ gene and a $p e p Q-$ like orf $Z$ gene (data not shown). The presence of orf $Z$ was also identified in $L b$. delbrueckii subsp. lactis DSM 20072 by PCR (data not shown). These results suggest that orf $Z$ may be commonly found in the genus Lactobacillus. This might argue in favour of a specific function for OrfZ.

\section{ACKNOWLEDGEMENTS}

The authors are grateful to Mrs Anneli Virta for the running of the A.L.F. Sequencer and Ms Jaana Jalava for technical assistance.

\section{REFERENCES}

Baankreis, R. \& Exterkate, F. (1991). Characterization of a peptidase from Lactococcus lactis ssp. cremoris $\mathrm{HP}$ that hydrolyses di- and tripeptides containing proline or hydrophobic residues as the aminoterminal amino acid. Syst Appl Microbiol 14, 317-323.

Biede, S. L. \& Hammond, E. G. (1979). Swiss cheese flavour. 1. Chemical analysis. J Dairy Sci 62, 227-237.

Booth, M., Jennings, V., Fhaolain, I. N. \& O'Cuinn, G. (1990). Prolidase activity of Lactococcus lactis subsp. cremoris AM2: partial purification and characterization. J Dairy Res 57, 245-254.

Chen, J. \& Morrison, D. (1987). Cloning of Streptococcus pneumoniae DNA fragments in Escherichia coli requires vectors protected by strong transcriptional terminators. Gene $\mathbf{5 5}$, 179-187.

Doi, E., Shibata, D. \& Matoba, T. (1981). Modified colorimetric ninhydrin methods for peptidase assay. Anal Biochem 118, 173-184.

Fernández-Esplá, M. D., Martin-Hernández, M. C. \& Fox, P. F. (1997). Purification and characterization of a prolidase from Lactobacillus casei subsp. casei IFPL 731. Appl Environ Microbiol 63, 314-316.

Fox, P. (1989). Proteolysis during cheese manufacture and ripening. J Dairy Sci 72, 1379-1400.

Gilbert, C., Atlan, D., Blanc, B. \& Portalier, R. (1994). Proline iminopeptidase from Lactobacillus delbrueckii subsp. bulgaricus CNRZ 397: purification and characterization. Microbiology 140, $537-542$.

Hames, B. \& Higgins, S. (1985). Nucleic Acid Hybridisation: a Practical Approach. Oxford, Washington, DC: IRL Press.
Jongeneel, C. V., Bouvier, J. \& Bairoch, A. (1989). A unique signature identifies a family of zinc-dependent metallopeptidases. FEBS Lett 242, 211-214.

Kaminogawa, S., Azuma, N., Hwang, I.-K., Suzuki, Y. \& Yamauchi, K. (1984). Isolation and characterization of a prolidase from Streptococcus cremoris H61. Agric Biol Chem 48, 3035-3040.

Klein, J. R., Schmidt, U. \& Plapp, R. (1994). Cloning, heterologous expression, and sequencing of a novel proline iminopeptidase gene, pepI, from Lactobacillus delbrueckii subsp. lactis DSM 7290. Microbiology 140, 1133-1139.

Klein, J. R., Schick, J., Henrich, B. \& Plapp, R. (1997). Lactobacillus delbrueckii subsp. lactis DSM7290 pepG gene encodes a novel cysteine aminopeptidase. Microbiology 143, 527-537.

Kok, J. (1990). Genetics of the proteolytic system of lactic acid bacteria. FEMS Microbiol Rev 87, 15-42.

Kok, J. \& De Vos, W. (1994). The proteolytic system of lactic acid bacteria. In Genetics and Biotechnology of Lactic Acid Bacteria, pp. 169-210. Edited by M. Gasson \& W. De Vos. Glasgow: Blackie Academic \& Professional.

Kunji, E. R. S., Mierau, I., Hagting, A., Poolman, B. \& Konings, W. N. (1996). The proteolytic systems of lactic acid bacteria. Antonie Leeuwenhoek 70, 187-221.

Miller, C. G. \& Schwartz, G. (1978). Peptidase deficient mutants of Escherichia coli. J Bacteriol 135, 603-611.

Myöhänen, S. \& Wahlfors, J. (1993). Automated fluorescent primer extension. BioTechniques 14, 16-17.

Palva, A., Nyberg, K. \& Palva, I. (1988). Quantitation of $\alpha$-amylase $m R N A$ in Bacillus subtilis by nucleic acid sandwich hybridization. DNA 7, 135-142.

Pouwels, P. H. \& Leunissen, J. A. M. (1994). Divergence in codon usage of Lactobacillus species. Nucleic Acids Res 22, 929-936.

Pritchard, G. \& Coolbear, T. (1993). The physiology and biochemistry of the proteolytic system in lactic acid bacteria. FEMS Microbiol Rev 12, 179-206.

Sambrook, J., Fritsch, E. F. \& Maniatis, T. (1989). Molecular Cloning: a Laboratory Manual, 2nd edn. Cold Spring Harbor, NY: Cold Spring Harbor Laboratory.

Sanger, F., Nicklen, S. \& Coulson, A. R. (1977). DNA sequencing with chain-terminating inhibitors. Proc Natl Acad Sci USA 74, 5463-5467.

Stucky, K., Klein, J., Schüller, A., Matern, H., Henrich, B. \& Plapp, R. (1995). Cloning and DNA sequence analysis of $p e p Q$, a prolidase gene from Lactobacillus delbrueckii subsp. lactis DSM7290 and partial characterization of its product. Mol Gen Genet 247, 494-500.

Tan, P., Poolman, B. \& Konings, W. (1993). Proteolytic enzymes of Lactococcus lactis. J Dairy Res 60, 269-286.

Tinoco, I., Borer, P. N., Dengler, B., Levine, M. D., Uhlenbech, O. C., Crothers, D. M. \& Gralla, J. (1973). Improved estimation of secondary structure in ribonucleic acids. Nature New Biol 246, $40-41$.

Troll, W. \& Lindsley, J. (1955). A photometric method for the determination of proline. J Biol Chem 215, 655-661.

Vesanto, E., Varmanen, P., Steele, J. L. \& Palva, A. (1994). Characterization and expression of the Lactobacillus belveticus pepC gene encoding a general aminopeptidase. Eur $J$ Biochem 224, 991-997.

Vesanto, E., Savijoki, K., Rantanen, T., Steele, J. L. \& Palva, A. (1995). An X-prolyl dipeptidyl aminopeptidase (pepX) gene from Lactobacillus helveticus. Microbiology 141, 3067-3075. 
Vidgren, G., Palva, I., Pakkanen, R., Lounatmaa, K. \& Palva, A. (1992). S-layer protein gene of Lactobacillus brevis: cloning by polymerase chain reaction and determination of the nucleotide sequence. J Bacteriol 174, 7419-7427.

Visser, S. (1993). Proteolytic enzymes and their relation to cheese ripening and flavor: an overview. J Dairy Sci 76, 329-350.

Wohlrab, Y. \& Bockelmann, W. (1992). Purification and characterization of a dipeptidase from Lactobacillus delbrueckii subsp. bulgaricus. Int Dairy J 2, 345-361.
Woodcock, D., Crowther, P., Doherty, J., Jefferson, S., De Cruz, E., Noyer-Weidner, M., Smith, S., Michael, M. \& Graham, M. (1989). Quantitative evaluation of Escherichia coli host strains for tolerance to cytosine methylation in plasmid and phage recombinants. Nucleic Acids Res 17, 3469-3478.

Received 23 April 1997; revised 21 August 1997; accepted 3 September 1997. 